\title{
Role of glycosylation in bovine leukemia virus infection
}

\author{
Amel-Baya Bouzar, Alix de Brogniez, Arnaud Florins, Carole François, Mathieu Boxus, Luc Willems \\ From 15th International Conference on Human Retroviruses: HTLV and Related Viruses \\ Leuven and Gembloux, Belgium. 5-8 June 2011
}

As a model for HTLV, reverse genetics can be used in the bovine leukemia virus (BLV) system to identify important mechanisms of viral persistence and pathogenesis. The question addressed here pertains to the role of glycans bound to the BLV envelope glycoprotein (SU gp51). Addition of carbohydrates to the BLV SU potentially creates a structure called "glycan shield" that confers resistance to the virus against the host immune response. On the other hand, glycosylation can also modulate attachment of the virus to the cell membrane.

To unravel the role of SU glycosylation, three complementary strategies were developed: pharmacological inhibition of different glycosylation pathways, interference with glycan attachment and site-directed mutagenesis of $\mathrm{N}$-glycosylation sites in an infectious BLV provirus. Collectively, our results demonstrate that glycosylation is important for the Gp51 maturation process, for virus infection in vitro and for infectivity in vivo.

Published: 6 June 2011

doi:10.1186/1742-4690-8-S1-A29

Cite this article as: Bouzar et al:: Role of glycosylation in bovine leukemia virus infection. Retrovirology 2011 8(Suppl 1):A29.

\footnotetext{
* Correspondence: AlixdeBrogniez@doct.ulg.ac.be

Cellular and Molecular Biology, Gembloux Agro-Bio Tech, University of Liege, Gembloux, Belgium
}

Submit your next manuscript to BioMed Central and take full advantage of:

- Convenient online submission

- Thorough peer review

- No space constraints or color figure charges

- Immediate publication on acceptance

- Inclusion in PubMed, CAS, Scopus and Google Scholar

- Research which is freely available for redistribution

\section{() Biomed Central}

\section{Biomed Central}

(C) 2011 Bouzar et al; licensee BioMed Central Ltd. This is an open access article distributed under the terms of the Creative Commons Attribution License (http://creativecommons.org/licenses/by/2.0), which permits unrestricted use, distribution, and reproduction in any medium, provided the original work is properly cited. 